\title{
Efficient one-pot four-component synthesis of fused thiazolopyridin-2-ones in ionic liquid
}

\author{
PRASHANT SINGH ${ }^{\mathrm{a}, \mathrm{b}, *}$, KAMLESH KUMARI $^{\mathrm{c}}$, GAURAV KAITHWAS $^{\mathrm{d}}$ \\ and GOPAL K MEHROTRA ${ }^{\mathrm{c}}$ \\ ${ }^{a}$ Atma Ram Sanatan Dharma College, University of Delhi, New Delhi 110 021, India \\ ${ }^{b}$ Department of Applied Chemistry, Babasaheb Bhimrao Ambedkar University, Lucknow 226025 , India \\ ${ }^{c}$ Department of Chemistry, Motilal Nehru National Institute of Technology, Allahabad 211004 , India \\ ${ }^{\mathrm{d}}$ Department of Pharmaceutical Sciences, Babasaheb Bhimrao Ambedkar University, Lucknow 226 025 , India \\ e-mail: arsdchemistry@yahoo.in
}

MS received 22 March 2012; revised 16 July 2012; accepted 3 October 2012

\begin{abstract}
An efficient one-pot synthesis of fused thiazolopyridinone derivatives (5-amino-6,7-diphenyl-4,7dihydro-3H-thiazolo[4,5-b]pyridin-2-ones) by four-component reaction of aldehyde, benzylcyanide, ammonium acetate and thiazolidine-2,4-dione in ionic liquid is reported. This protocol has the advantages of environmental friendliness, higher yields, less reaction time, and convenient operation. Also, optimization of the synthesized compounds has been done using Hyperchem 8.0.
\end{abstract}

Keywords. One-pot synthesis; thiazolopyridinone derivatives; multicomponent reactions; ionic liquid.

\section{Introduction}

Multi-component reactions (MCRs) in which several reactions are combined into one synthetic operation has been used extensively to form carbon-carbon bonds in the synthetic chemistry. Such reactions offer a wide range of possibilities for the efficient construction of highly complex molecules in a single procedure step, thus avoiding the complicated purification operations and allowing savings of both solvents and reagents. Thus, they are perfectly amenable to automation for combinatorial synthesis. In the last few decades, there have been tremendous development in three- as well as four-component reactions and greater efforts are being continued to develop new MCRs. Thiazoles and pyrazoles are gaining importance in medicinal and organic chemistry. They have shown broad spectrum of pharmacological and biological activities, such as antibacterial, antidepressant, antihyperglycemic, antiinflammatory, and antitumour. ${ }^{1-6}$ Many of the methods reported for the synthesis of organic compounds are associated with the use of hazardous organic solvents, long reaction time, and lack of general applicability. ${ }^{7}$

Room temperature ionic liquids (RTILs), have shown as an attractive substitute to conventional organic

*For correspondence solvents, and more attention has been currently drawn on organic reactions promoted by ionic liquids. They are non-volatile, recyclable, eco-friendly, nonexplosive, easily operable, and thermally robust. ${ }^{8-10} \mathrm{We}$ described here a simple and efficient synthesis of thiazolopyridinone derivatives (5-amino-6,7-diphenyl-4, 7-dihydro-3H-thiazolo[4,5-b]pyridin-2-ones) by fourcomponent reaction of aldehyde, benzonitrile, ammonium acetate and thiazolidine-2,4-dione in ionic liquid without any catalyst. Also, the optimization and QSAR properties of the synthesized compounds have been evaluated using Hyperchem 8.0.

\section{Experimental}

\subsection{General information}

Unless indicated, reagents and solvents were purchased from SRL and Merck, India Aldrich chemicals and used without purification, with the following exceptions. Methanol and dimethyl formamide were distilled from calcium hydride under nitrogen. Flash column chromatography was performed using silica gel 60 (Merck) with indicated solvents. Thin-layer chromatography (TLC) was performed using Kieselgel $\mathrm{F}_{254}$ plates (Merck). Infrared spectra were recorded on a Jasco FT/IR 430 spectrometer. ${ }^{1} \mathrm{H}$ - and ${ }^{13} \mathrm{C}-\mathrm{NMR}$ 
spectra were recorded on Toxi-Spin $300 \mathrm{MHz}$ spectrometer as solutions in deuteriochloroform $\left(\mathrm{CDCl}_{3}\right)$ or deuteriodimethyl sulphoxide $\left(\left(\mathrm{CD}_{3}\right)_{2} \mathrm{SO}\right)$. Chemical shifts are expressed in parts per million (ppm, $\delta$ ) downfield from an internal standard, tetramethylsilane. Optimization of the synthesized compounds has been done using Hyperchem 8.0.

\subsection{General procedure for the synthesis of thiazolopyridinone (compound 5aa)}

A dry $100 \mathrm{~mL}$ flask was charged with thiazolidine2, 4-dione 1 ( $5 \mathrm{mmol})$, benzaldehyde $\mathbf{2 a}(5 \mathrm{mmol})$, benzylcyanide 3a $(5 \mathrm{mmol})$ and ammonium acetate 4 $(5.2 \mathrm{mmol})$, and ionic liquid [bmim] Br $(15 \mathrm{~mL})$. The mixture was stirred at $90^{\circ} \mathrm{C}$ for appropriate time to complete the reaction and it was monitored by thinlayer chromatography. Then, $50 \mathrm{~mL}$ water was added. The solid was filtered off and washed with water. The crude product was purified by recrystallization from ethanol to afford the product and well characterized by FTIR, proton and carbon NMR, which confirm the sturcture of the compound.

Similarly, other derivatives are being synthesized by varying the reactants and characterized by FTIR, proton and carbon NMR techniques.

\section{Result and discussion}

To overcome the disadvantages such as volatility and toxicity (many organic solvents inherently have), we employed RTILs into the four-component reaction as<smiles>N#CCc1ccccc1</smiles>

Scheme 1. One-pot synthesis of thiazolopyridin-2-ones.

Table 1. Optimization of reaction conditions (solvent, mol ratio and temperature of the reactants) for the catalyst-free multicomponent reactions. ${ }^{\mathrm{a}}$

\begin{tabular}{|c|c|c|c|c|c|}
\hline Sl. No. & Solvent & Mol ratio (1:2a:3a:4) & Time (h) & Temp $\left({ }^{\circ} \mathrm{C}\right)$ & Yield (\%) \\
\hline 1 & Dioxane & $1: 1: 1: 1$ & 8 & 30 & 65 \\
\hline 2 & Acetonitrile & 1:1:1:1 & 10 & 30 & 64 \\
\hline 3 & DMF & 1:1:1:1 & 12 & 30 & 65 \\
\hline 4 & Toluene & $1: 1: 1: 1$ & 8 & 30 & 50 \\
\hline 5 & Water & $1: 1: 1: 1$ & 60 & 30 & No reaction \\
\hline 6 & DMSO & 1:1:1:1 & 12 & 30 & 55 \\
\hline 7 & THF & $1: 1: 1: 1$ & 6 & 30 & 70 \\
\hline 8 & {$\left[\mathrm{Net}_{3}\right][\mathrm{Ac}]$} & $1: 1: 1: 1$ & 3 & 30 & 80 \\
\hline 9 & {$[\mathrm{bmim}][\mathrm{Cl}]$} & 1:1:1:1 & 3 & 30 & 78 \\
\hline 10 & {$[\mathrm{bmim}][\mathrm{Br}]$} & 1:1:1:1 & 2 & 30 & 80 \\
\hline 11 & {$[\mathrm{bmim}][\mathrm{Br}]$} & 1:1:1:1.1 & 2 & 30 & 82 \\
\hline 12 & {$[\mathrm{bmim}][\mathrm{Br}]$} & 1:1:1.1:1.1 & 2 & 30 & 84 \\
\hline 13 & {$[\mathrm{bmim}][\mathrm{Br}]$} & $1: 1: 1: 1.2$ & 2 & 30 & 79 \\
\hline 14 & {$[\mathrm{bmim}][\mathrm{Br}]$} & 1:1:1:0.9 & 2 & 30 & 72 \\
\hline 15 & {$[\mathrm{bmim}][\mathrm{Br}]$} & 1:1:1:0.8 & 2 & 30 & 65 \\
\hline 16 & {$[\mathrm{bmim}][\mathrm{Br}]$} & 1:1:1.1:1.1 & 2 & 45 & 82 \\
\hline 17 & {$[\mathrm{bmim}][\mathrm{Br}]$} & 1:1:1.1:1.1 & 2 & 60 & 90 \\
\hline 18 & {$[\mathrm{bmim}][\mathrm{Br}]$} & 1:1:1.1:1.1 & 2 & 80 & 94 \\
\hline
\end{tabular}

${ }^{a}$ Reactions were carried out amongst thiazolidine-2,4-dione (1), benzaldehyde (2a), benzylcyanide (3a) and ammonium acetate $(\mathbf{4})$ in a solvent $(15 \mathrm{~mL})$ 
Table 2. Catalyst-free one-pot synthesis of 9-phenyl-3,9-dihydro-chromeno [2,3-d] thiazol-2-one via MCRs in thiazolidine-2,4-dione, aromatic aldehyde and urea derivative.

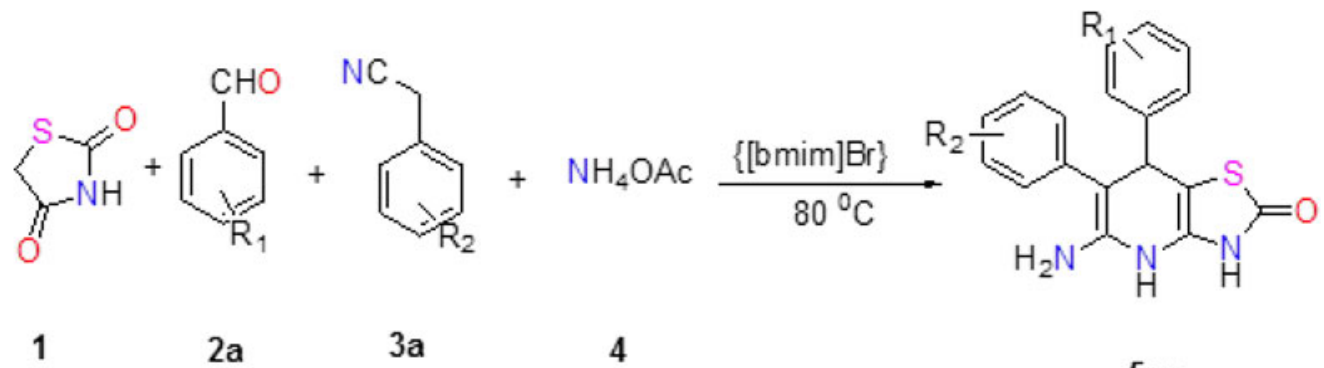

Equivalent $1: 1: 1.1: 1.1$

Sl. No. Reactant ${ }^{2} \quad$ Reactant $^{3} \quad$ Product $\quad$ Compound no. Time (h) Yield (\%)

1<smiles>N#CCc1ccccc1</smiles>

2<smiles>O=Cc1ccccc1</smiles><smiles>Cc1ccc(CC#N)cc1</smiles>

3<smiles>O=Cc1ccccc1</smiles><smiles>COc1ccc(CC#N)cc1</smiles>

4<smiles>O=Cc1ccccc1</smiles><smiles>N#CCc1ccc(Cl)cc1</smiles>

5<smiles>N#CCc1ccc(Br)cc1</smiles><smiles>NC1=C(c2ccccc2)C(c2ccccc2)c2sc(=O)[nH]c2N1</smiles>

5 aa

2.5 94

$5 a b$

2.5

88<smiles>Cc1ccc(C2=C(N)Nc3[nH]c(=O)sc3C2c2ccccc2)cc1</smiles>

5 ac

2.5

90<smiles>COc1ccc(C2=C(N)Nc3[nH]c(=O)sc3C2c2ccccc2)cc1</smiles>

5 ad

2.5 95<smiles>NC1=C(c2ccc(Cl)cc2)C(c2ccccc2)c2sc(=O)[nH]c2N1</smiles><smiles>NC1=C(c2ccc(Br)cc2)C(c2ccccc2)c2sc(=O)[nH]c2N1</smiles>

5 ae

4.0

90 
Table 2. (Continued).

\begin{tabular}{|c|c|c|c|c|c|c|}
\hline Sl. No. & Reactant $^{2}$ & Reactant $\mathrm{t}^{3}$ & Product & Compound no. & Time (h) & Yield (\%) \\
\hline 6 & $\mathrm{CHO}$ & $\mathrm{CN}$ & & 5 af & 5.0 & 98 \\
\hline 7 & $\mathrm{CHO}$ & $\mathrm{CN}$ & $\mathrm{Cl}$ & $5 \mathrm{ag}$ & 6.0 & 90 \\
\hline 8 & $\mathrm{CHO}$ & $\mathrm{CN}$ & $\mathrm{Br}$ & $5 \mathrm{ah}$ & 7.5 & 85 \\
\hline 9 & $\mathrm{CHO}$ & $\mathrm{CN}$ & $\mathrm{F}$ & 5ai & 4.0 & 85 \\
\hline 10 & $\mathrm{CHO}$ & $\mathrm{CN}$ & $\mathrm{OMe}$ & 5aj & 9.5 & 84 \\
\hline 11 & $\mathrm{CHO}$ & $\mathrm{CN}$ & & $5 \mathrm{ak}$ & 8.5 & 90 \\
\hline
\end{tabular}


a green medium. Initially, the four-component reaction of thiazolidine-2, 4-dione $\mathbf{1}$, benzaldehyde $\mathbf{2 a}$, benzylcyanide $\mathbf{3 a}$ and ammonium acetate $\mathbf{4}$ as a simple model substrate was investigated to establish the feasibility of the strategy and to optimize the reaction conditions to afford 5aa (scheme 1).

Table 2. (Continued).

Sl. No. Reactant ${ }^{2} \quad$ Reactant $^{3} \quad$ Product

13<smiles>O=Cc1ccc(Br)cc1</smiles><smiles>Cc1ccc(CC#N)cc1</smiles><smiles>Cc1ccc(C2=C(N)Nc3[nH]c(=O)sc3C2c2ccc(Br)cc2)cc1</smiles>

5 am<smiles>O=Cc1ccc(F)cc1</smiles><smiles>Cc1ccc(CC#N)cc1</smiles><smiles>Cc1ccc(C2=C(N)Nc3[nH]c(=O)sc3C2c2ccc(F)cc2)cc1</smiles>

5an<smiles>O=Cc1cccc([N+](=O)[O-])c1</smiles><smiles>Cc1ccc(CC#N)cc1</smiles><smiles>Cc1ccc(C2=C(N)Nc3[nH]c(=O)sc3C2c2cccc([N+](=O)[O-])c2)cc1</smiles><smiles>O=Cc1ccc(Cl)cc1</smiles><smiles>COc1ccc(CC#N)cc1</smiles><smiles>COc1ccc(C2=C(N)Nc3[nH]c(=O)sc3C2c2ccc(Cl)cc2)cc1</smiles> 
Screening of the reaction conditions was established by using suitable solvents, the mol ratio of reactants as well as temperature for the desired MCRs (table 1). It was exciting that the chosen solvents such as dioxane, N,N-dimethylformamide (DMF), acetonitrile $\left(\mathrm{CH}_{3} \mathrm{CN}\right)$, dimethylsulphoxide (DMSO), toluene,

Table 2. (Continued).

\begin{tabular}{|c|c|c|c|c|c|c|}
\hline Sl. No. & Reactant $t^{2}$ & Reactant $\mathrm{t}^{3}$ & Product & Compound no. & Time (h) & Yield (\%) \\
\hline 17 & $\mathrm{CHO}$ & $\mathrm{CN}$ & $\mathrm{Br}$ & $5 \mathrm{aq}$ & 6.5 & 86 \\
\hline
\end{tabular}

18<smiles>O=Cc1ccc(F)cc1</smiles><smiles>COc1ccc(CC#N)cc1</smiles><smiles>COc1ccc(C2=C(N)Nc3[nH]c(=O)sc3C2c2ccc(F)cc2)cc1</smiles><smiles>COc1ccc(C=O)cc1</smiles><smiles>COc1ccc(CC#N)cc1</smiles><smiles>COc1ccc(C2=C(N)Nc3[nH]c(=O)sc3C2c2ccc(OC)cc2)cc1</smiles><smiles>O=Cc1cccc([N+](=O)[O-])c1</smiles><smiles>COc1ccc(CC#N)cc1</smiles><smiles>COc1ccc(C2=C(N)Nc3[nH]c(=O)sc3C2c2cccc([N+](=O)[O-])c2)cc1</smiles><smiles>N#CCc1ccc(Cl)cc1</smiles><smiles>NC1=C(c2ccc(Cl)cc2)C(c2ccc(Cl)cc2)c2sc(=O)[nH]c2N1</smiles> 
etc. were suitable for the MCRs (table 1, entries 1-10). Ionic liquid ([bmim] Br) proved to be the best among them (table 1, entry 10). While under water, no product has been formed even after $60 \mathrm{~h}$ (table 1 , entry 5 ). To modulate the ratio of reactants and improve the yield, we examined various ratios of thiazolidine-2, 4-dione

Table 2. (Continued).

\begin{tabular}{|c|c|c|c|c|c|c|}
\hline Sl. No. & Reactant ${ }^{2}$ & Reactant ${ }^{3}$ & Product & Compound no. & Time (h) & Yield (\%) \\
\hline 22 & $\mathrm{CHO}$ & $\mathrm{CN}$ & $\mathrm{Br}$ & 5 av & 8.0 & 80 \\
\hline
\end{tabular}

23<smiles>O=Cc1ccc(F)cc1</smiles><smiles>N#CCc1ccc(Cl)cc1</smiles>

5aw<smiles>COc1ccc(C=O)cc1</smiles><smiles>N#CCc1ccc(Cl)cc1</smiles>

$\mathrm{Cl}$<smiles>NC1=C(c2ccc(I)cc2)C(c2ccc(F)cc2)c2sc(=O)[nH]c2N1</smiles>

5 ax<smiles>O=Cc1cccc([N+](=O)[O-])c1</smiles><smiles>N#CCc1ccc(Cl)cc1</smiles>

$\mathrm{Cl}$<smiles>COc1ccc(C2C(c3ccc(I)cc3)=C(N)Nc3[nH]c(=O)sc32)cc1</smiles><smiles>NC1=C(c2ccc(Cl)cc2)C(c2cccc([N+](=O)[O-])c2)c2sc(=O)[nH]c2N1</smiles>

5ay<smiles>N#CCc1ccc(Br)cc1</smiles><smiles>NC1=C(c2ccc(Br)cc2)C(c2ccc(Cl)cc2)c2sc(=O)[nH]c2N1</smiles> 
$\mathbf{1}$, benzaldehyde $\mathbf{2 a}$, benzylcyanide $\mathbf{3 a}$ and ammonium acetate 4 by using acetonitrile as a solvent (table 1 , entries 11-15). The best result obtained when the ratio of thiazolidine-2, 4-dione $\mathbf{1}$, benzaldehyde $\mathbf{2 a}$, benzylcyanide $\mathbf{3 a}$ and ammonium acetate $\mathbf{4}$ is $1: 1: 1.1: 1.1$ to afford the product 4a i.e., entry 12. Further, optimization of temperature was done (table 1, entries 16-18) and we found the best yield at $90^{\circ} \mathrm{C}$ (entry 17). With the optimized conditions in hand, we examined the scope of the multicomponent reaction (table 2, entries 1-30). We found that the reaction proceeded smoothly, and the desired products in excellent yields. The ionic liquid used for the transformation was recovered and used for further reaction and to obtain good yields (table 3 ).
Hyperchem 8.0 is a powerful computational software developed by Hypercube Inc, Gainsville USA for molecular and quantum mechanics calculations. To understand the properties of a designated molecule, we need to generate a well-defined structure that represents a minimum on a potential energy surface. Hyperchem provides parameters to enable geometry optimization so as to deduce a structure with minimum energy. The QSAR approach has proved extremely useful to identify and quantify the physico-chemical properties of an organic molecule. The geometry of thiazolidine-2, 4-dione and its derivatives has been optimized based on semi-empirical calculations, using the molecular modelling program Hyperchem 8.0. Various parameters

Table 2. (Continued).

\begin{tabular}{|c|c|c|c|c|c|c|}
\hline Sl. No. & Reactant $^{2}$ & Reactant $^{3}$ & Product & Compound no. & Time (h) & Yield (\%) \\
\hline 27 & $\mathrm{CHO}$ & $\mathrm{CN}$ & $\mathrm{Br}$ & 5 ba & 3.0 & 90 \\
\hline 28 & $\mathrm{CHO}$ & $\mathrm{CN}$ & $F$ & $5 \mathbf{b b}$ & 2.5 & 86 \\
\hline 29 & $\mathrm{CHO}$ & $\mathrm{CN}$ & ON & $5 b c$ & 5.5 & 86 \\
\hline 30 & $\mathrm{CHO}$ & $\mathrm{CN}$ & & $5 \mathrm{bd}$ & 6.5 & 85 \\
\hline
\end{tabular}


Table 3. Optimization of the activity of ionic liquid after reuse.

\begin{tabular}{lcc}
\hline Sl. No. & No. of cycle & Yield (\%) \\
\hline 1 & I & 94 \\
3 & II & 94 \\
3 & III & 92 \\
4 & IV & 92 \\
5 & V & 90 \\
\hline
\end{tabular}

were applied to calculate molecular properties of synthesized compounds like surface area, volume, refractivity, polarizability, hydrophobicity $(\log P)$, and hydration energy. The structure of thiazolidine-2,4dione was taken from invoke database using single point calculation parameter, the molecular energy and gradient for a given fixed geometry was set. Further geometry optimization calculations were employed for energy minimization algorithms to find the most stable conformation. Geometry optimization was taken as criteria to determine the most stable conformer for compounds as in table S1. Hydrophobicities of compounds can be readily determined by measuring partition coefficients designated as $P$. Partition coefficients dealing with neutral species. By convention, $P$ is defined as the ratio of concentration of the drugs in octanol to its concentration in water. More the value of $\log P$, more will be the hydrophobicity. The values for $\log P$ and other parameters for the following pairs \{(5aa and 5ab), (5ap, 5aq and 5as), (5au and 5av) and (5aw and 5ax) $\}$ are of same values for the compounds as in table $\mathrm{S} 1 . \log P$ value for the synthesized compounds varies from -0.58 to -2.36 which indicates that lesser the value of $\log P$, more will be hydrophilic. Therefore, compound 5ar is the most hydrophilic in nature.

\section{Conclusion}

We have described an efficient one-pot, four-component reaction of thiazolidine-2, 4-dione, benzaldehyde, benzonitrile and ammonium acetate, for the synthesis of 5-amino-6,7-diphenyl-4,7-dihydro-3H-thiazolo[4,5b]pyridin-2-one derivatives in ionic liquid $\{[\mathrm{bmim}] \mathrm{Br}\}$. This method has the advantages of high yields, mild reaction conditions, short reaction time, convenient procedure, and environmental friendliness. Given the large number of commercially available building blocks, the present method should be applicable to synthesis of libraries with high diversity.

\section{Supplementary information}

Table S1 and analytical data can be seen in www.ias. ac.in/chemsci website.

\section{Acknowledgements}

Authors thank the University Grant Commission (UGC) and the Department of Science and Technology (DST), New Delhi, India.

\section{References}

1. (a) Cantello B C C, Cawthorne M A, Cottam G P, Duff P T, Haigh D, Hindley R M, Lister C A, Smith S A and Thurlby P L 1994 J. Med. Chem. 37 3977; (b) Reaven G M 1988 Diabetes 371595

2. (a) Chen C, Xu S, Wang W X, Ding Y M, Yu K H, Wang B and Chen X Y 2009 Arch. Med. Res. 40 79; (b) Cruz P D L, Diez-Barra E, Loupy A and Langa F 1996 Tetrahedron Lett. 37 1113; (c) Aronoff S, Rosenblatt S, Braithwaite S, Egan J W, Mathisen A L and Schneider R L 2000 Diabetes Care 231605

3. (a) Barnett D, Craig J G, Robinson D S and Rogers M P 1977 Br. J. Clin. Pharmacol. 4 455; (b) Berger $\mathrm{J}$ and Moller D E 2002 Annu. Rev. Med. 53 409; (c) Cantello B C, Cawthorne M A, Cottam G P, Duff P T, Haigh D, Hindley R M, Lister C A, Smith S A and Thurlby P L 1994 J. Med. Chem. 37 3977; (d) Cox S L 2006 Drugs Today (Barc) 42 139, Desvergne B and Wahli W 1999 Endocrinol. Rev. 20 649; (e) Devasthale P V, Chen S, Jeon Y, Qu F, Shao C, Wang W, Zhang H, Cap M, Farrelly D and Golla R 2005 J. Med. Chem. 48 2248; (f) Ibrahimi A, Teboul L, Gaillard D, Amri E Z, Ailhaud G, Young P, Cawthorne M A and Grimaldi P A 1994 Mol. Pharmacol. 461070

4. (a) Kersten J R, Toller W G, Gross E R, Pagel P S and Warltier D C 2000 Am. J. Physiol. Heart Circ. Physiol. 278 H1218; (b) Kletzien R F, Clarke S D and Ulrich R G 1992 Mol. Pharmacol. 41 393; (c) Lehmann J M, Moore L B, Smith-Oliver T A, Wilkison W O, Willson T M and Kliewer S A 1995 J. Biol. Chem. 270 12953; (d) Ljung B, Bamberg K, Dahllof B, Kjellstedt A, Oakes N D, Ostling J, Svensson L and Camejo G 2002 J. Lipid Res. 43 1855; (e) Sohda T, Momose Y, Meguro K, Kawamatsu Y, Sugiyama Y and Ikeda H 1990 Arzneimittelforschung 40 37; (f) Yajima K, Hirose H, Fujita H, Seto Y, Fujita H, Ukeda K, Miyashita K, Kawai T, Yamamoto Y, Ogawa T, Yamada T and Saruta T 2003 Am. J. Physiol. Endocrinol. Metabol. 284 E966; (g) Yoshioka T, Fujita T, Kanai T, Aizawa Y, Kurumada T, Hasegawa K and Horikoshi H 1989 J. Med. Chem. 32421

5. (a) Bienayme H, Hulme C, Oddon G and Schmitt P 2000 Chem. Eur. J. 6 3321; (b) Tietze L F and Modi A 2000 Med. Res. Rev. 20 304; (c) Deomling A and Ugi I 2000 Angew. Chem. Int. Ed. 39 3168; (d) Zhu J 2003 Eur. J. Org. Chem. 1133; (e) Orru R V A and de Greef M 2003 Synthesis 1471; (f) Nair V, Rajesh C, Vinod A U, Bindu S, Sreekanth A R, Mathen J S and Balagopal L 2003 
Acc. Chem. Res. 36 899; (g) Simon C, Constantieux T and Rodriguez J 2004 Eur. J. Org. Chem. 4957

6. (a) Yuan Y, Li X and Ding K 2002 Org. Lett. 4 3309; (b) Cheng J F, Chen M, Arrhenius T and Nadzen A 2002 Tetrahedron Lett. 43 6293; (c) Huma H Z S, Halder R, Kalra S S, Das J and Iqbal J 2002 Tetrahedron Lett. 43 6485; (d) Bora U, Saikia A and Boruah R C 2003 Org. Lett. 5 435; (e) Dallinger D, Gorobets N Y and Kappe C O 2003 Org. Lett. 51205

7. (a) Hardy C R 1984 Adv. Heterocycl. Chem. 36 343; (b) Orth R E 1968 J. Pharm. Sci. 57 537; (c) Elnagdi M H, Elmoghayar M R H and Elgemeie G E H 1987 Adv. Heterocycl. Chem. 41 319; (d) Elnagdi M H, Elmoghayar M R H and Sadek K U 1990 Adv. Heterocycl. Chem. 48 223; (e) Liu X H, Cui P, Song B A, Bhadury P S, Zhu H L and Wang S F 2008 Bioorg. Med. Chem. 16 4075; (f) Palaska E, Aytemir M, Uzbay T and Erol D 2001 Eur. J. Med. Chem. 36 539; (g) Kees K L, Fitzgerald J J, Steiner K E Jr, Mattes J F, Mihan B, Tosi T, Mondoro D and McCaleb M L J 1996 Med. Chem. 393920

8. (a) Singh P, Katyal A, Kalra R and Chandra R 2008 Tet. Lett. 42, 727; (b) Singh P, Katyal A, Kalra R and Chandra R 2009 Spectro. Chim. Acta A 73, 218; (c) Kumari K, Singh P, Srivastava R C, Kumar P, Mehrotra G K, Samim M, Chandra R and Mordhwaj 2011 CPHEE Perspectives 69, 329; (d) Singh P,
Kumari K, Dubey M, Vishwakarma V K, Pandey N D, Chandra R and Mehrotro G K 2012 Competes rendusChimie 15, 504; (e) Kumari K, Singh P, Dubey M, Pandey N D, Chandra R and Mehrotro G K 2012 Competes rendus-Chimie 15 267; (f) Singh P, Kumar P, Kumari K, Sharma P, Mozumdar S and Chandra R 2011 Spect. Acta A: Mol. Biomol. Spect. 78 909; (g) Singh P, Kumari K, Katyal A, Kalra R and Chandra R 2009 Cat. Lett. 127, 119; (h) Singh P, Kumari K, Katyal A, Kalra R and Chandra R 2009 Cat. Lett. 130, 648; (i) Singh P, Kumar S, Katyal A, Kalra R and Chandra R 2008 Mat. Lett. 62, 4164; (j) Singh P, Katyal A, Kalra R and Chandra R 2008 Cat. Commun. 9, 1618

9. (a) Dzyuba S V and Bartsch R 2003 Angew. Chem. Int. Ed. 42 148; (b) Wilker J S 2002 Green Chem. 473 (10) (c) Welton T 1999 Chem. Rev. 99 2071; (d) Dupont J, de Souza R F and Suarez P A Z 2002 Chem. Rev. 102 3667

10. (a) Fischer T, Sethi A, Welton T and Woolf J 1999 Tetrahedron Lett. 40 793; (b) Lee C W 1999 Tetrahedron Lett. 40 2461; (c) Ludley P and Karodia N 2001 Tetrahedron Lett. 42 2011; (d) Carmichael A J, Earle M J, Holbrey J D, McCormac P B and Seddon K R 1999 Org. Lett. 1, 997; (e) Calo V, Nacci A, Lopez L and Mannarini N 2000 Tetrahedron Lett. 418973 